\title{
HUBUNGAN PERILAKU KONSUMSI MINUMAN BERALKOHOL DENGAN GEJALA GASTRITIS PADA SEKAA TERUNA TERUNI (STT) DI DESA X, KECAMATAN PETANG, KABUPATEN BADUNG
}

\author{
${ }^{1}$ I Made Ghora Palguna, ${ }^{2}$ Made Oka Ari Kamayani, ${ }^{3}$ I Made Suindrayasa \\ ${ }^{123}$ Program Studi Sarjana Keperawatan dan Profesi Ners Fakultas Kedokteran Universitas Udayana \\ Email : ghorapalguna@gmail.com
}

\begin{abstract}
Abstrak
Pengaruh globalisasi merupakan faktor yang dapat menyebabkan perubahan perilaku pada masyarakat baik positif maupun negatif, salah satu perilaku negatif yang timbul yaitu perilaku konsumsi minuman beralkohol. Dampak negatif yang ditimbulkan bagi kesehatan, salah satunya gangguan pada sistem gastrointestinal yaitu gastritis. Tujuan penelitian ini adalah untuk mengetahui hubungan antara perilaku konsumsi minuman beralkohol dengan gejala gastritis pada Sekaa Teruna Teruni di Desa X Kecamatan Petang Kabupaten Badung. Desain penelitian mengunakan desain deskriptif korelasi dengan menggunakan pendekatan cross sectional. Sampel penelitian yang digunakan sebanyak 84 remaja. Teknik sampling yang digunakan dalam penelitian ini adalah Non-Probability Sampling dengan teknik Quota Sampling. Instrumen yang digunakan adalah kuisioner perilaku konsumsi minuman beralkohol dan kuisioner gejala gastritis. Metode analisa data yang digunakan yaitu korelasi spearman dengan menggunakan SPSS. Pada penelitian ini diperoleh nilai $p$ 0,001 dengan nilai korelasi sebesar 0,541 yang menunjukan bahwa kolerasi antara perilaku konsumsi minuman beralkohol dan gejala gastritis bermakna dan nilai korelasi positif dengan kekuatan korelasi sedang. sehingga dapat disimpulkan bahwa ada hubungan antara perilaku mengkonsumsi minuman beralkohol dengan gejala gastritis pada Sekaa Teruna Teruni di Desa X, Kecamatan Petang, Kabupaten Badung. Saran bagi Sekaa Teruna Teruni agar mengkontrol perilaku konsumsi minuman beralkohol sehingga dampak negatifnya seperti gastritis dapat berkurang.
\end{abstract}

Kata Kunci : Perilaku, Minuman Berlkohol, Gastritis

\begin{abstract}
The influence of globalization is a factor that can cause changes in behavior in society both positive and negative, one of the negative behaviors that arise is the behavior of consuming alcoholic beverages. Negative impacts caused for health, one of which is the gastrointestinal system, namely gastritis. The purpose of this study was to determine the relationship between alcoholic beverage consumption behavior with gastritis symptoms in Sekaa Teruna Teruni in X Village, Petang District, Badung Regency. The research design uses descriptive correlation design using a cross sectional approach. The research sample used was 84 teenagers. The sampling technique used in this study was the Non-Probability Sampling with Quota Sampling technique. The instrument used was a questionnaire on the consumption of alcoholic beverages and a gastritis symptom questionnaire. Data analysis method used is spearman correlation using SPSS. In this study obtained p value of 0.001 with a correlation value of 0.541 which indicates that the correlation between alcoholic beverage consumption behavior and symptoms of gastritis is significant and a positive correlation value with moderate correlation strength. so it can be concluded that there is a relationship between the behavior of consuming alcoholic beverages with gastritis symptoms in Sekaa Teruna Teruni in Village X, District of Petang, Badung Regency. Advice for Sekaa Teruna Teruni to control the behavior of consuming alcoholic beverages so that the negative effects such as gastritis can be reduced.
\end{abstract}

Keywords: Behavior, Alcoholic Beverages, Gastritis 


\section{PENDAHULUAN}

Pengaruh globalisasi merupakan faktor kemungkinan yang dapat menyebabkan perubahan perilaku pada masyarakat. Perkembangan jaman menjadi sebuah tuntutan bagi setiap orang untuk berubah menjadi lebih maju (Saufika, 2012). Dewasa ini banyak sekali masyarakat Indonesia cenderung memilih kebiasaankebiasaan yang berdampak buruk bagi diri mereka seperti perilaku seks bebas, perilaku kriminalitas,dan salah satunya adalah perilaku mengkonsumsi alkohol yang mana perilaku ini merupakan sebuah kebiasaan yang kurang baik bagi kesehatan ini sering ditemui di masyarakat pada umumnya (Kant, 2013). Di beberapa negara termasuk Indonesia minuman beralkohol ini banyak disalah gunakan karena akses untuk mendapatkan minuman beralkohol sangat mudah, sehingga semua rentang umur dapat mengkonsumsi minuman alkohol tersebut. (Wiria, 2009).

Data dari WHO tahun 2013, prevalensi perilaku mengkonsumsi alkohol di Indonesia cukup besar, tercatat 91 juta orang yang mengkonsumsi alkohol pada tahun 2013 jumlah tersebut 46\% pengguna alkohol adalah remaja hingga dewasa awal yang paling sering mengkonsumsi minumal alkohol (Utina, 2012). Sedangkan menurut Riskesdas (2018) menyatakan bahwa Bali merupakan provinsi yang peningkatan perilaku konsumsi alkoholnya meningkat sangat signifikan, dimana awalnya pada tahun 2007 hanya 5\% dari total penduduk usia $>10$ tahun yang mengkonsumsi alkohol meningkat menjadi hampir $15 \%$ di tahun 2018. Hal tersebut dapat menggambarkan perilaku kesehatan yang kurang baik dari masyarakat Indonesia. Mengkonsumsi alkohol sangat berdampak besar bagi kesehatan.
Mengkonsumsi alkohol terlalu banyak dapat memicu terjadinya gangguan pada otak, dapat merusak hepar, gangguan pada ginjal, gangguan reproduksi, mengganggu perkembangan prenatal, sistem gastroitntestinal, kardiovaskular, sistem saraf pusat dan dapat memicu terjadinya kanker yang berdampak terhadap kematian (Utina, 2011). Salah satu dampak negatif yang ditimbulkan karena mengkonsumsi alkohol adalah gangguan pada saaluran gastrointestinal yaitu gastritis. Mengkonsumsi minuman beralkohol dapat menyebabkan iritasi dan pemgikisan mukosa pada dinding lambung, minuman beralkohol memiliki sifat korosif sehingga dinding lambung rentan terhadap asam lambung yang akan menyebabkan perdarahan pada lambung (Silvia, 2013).

Gejala yang timbul pada penyakit gastritis adalah nyeri pada perut, mual, perut kembung, dan sakit kepala (Saydam, 2011). Gastritis apabila tidak ditangani dengan baik dapat mengakibatkan kekambuhan secara berkala dan memberikan efek negatif pada kesehatan. Berdasarkan studi pendahuluan yang dilakukan di Desa X, Kecamatan Petang Kabupaten Badung Bali pada hari minggu tanggal 13 Desember 2019 didapatkan data, dari hasil wawancara dengan sepuluh responden (100\%) didapatkan hasil semua responden memiliki perilaku mengkonsumsi minuman alkohol, 60\% responden sudah memulai perilaku mengkonsumsi minuman beralkohol sejak antara 6 sampai 7 tahun yang lalu dan $40 \%$ responden lainnya hanya mengkonsumsi alkohol pada hari-hari raya tertentu saja. Sepuluh responden yang telah diwawancarai $60 \%$ responden ini pernah mengalami gejala-gejala gastritis seperti nyeri pada ulu hati, mual dan muntah serta rasa tidak nyaman pada perut dan $40 \%$ responden tidak mengalami gejala-gejala gastritis. 
Berdasarkan dari latar belakang tersebut peneliti ingin meneliti lebih lanjut mengenai hubungan perilaku mengkonsumsi minuman beralkohol dengan gejala gastritis pada Sekaa Teruna Teruni (STT) di Desa X Petang Kabupaten Badung.

\section{METODE PENELITIAN}

Penelitian ini merupakan penelitian kuantitatif. Penelitian ini termasuk penelitian non eksperimental. Rancangan yang digunakan pada penelitian ini adalah deskriptif korelasional. Model pendekatan subyek yang dipergunakan adalah cross sectional. Uji bivariat yang digunakan adalah uji non-parametris korelasi Spearman Rank.

Populasi dalam penlitian ini adalah Sekaa Teruna Teruni (STT) yang terdiri dari 3 Sekaa Teruna Teruni pada pada 5 Banjar yang berjumlah 106 orang. Sampel pada penelitian ini adalah 84 .

Instrumen pengumpulan data yang digunakan dalam penelitian ini adalah kuesioner perilaku konsumsi minuman beralkohol untuk menilai perilaku konsumsi minuman beralkohol. Data gejala gastritis dikumpulkan menggunakan kuesioner gejala gastritis.

Prosedur pengumpulan data dilakukan dengan mengajukan surat izin ke Badan Perizinan dan Penanaman Modal Provinsi Bali. Meneruskan surat rekomendasi penelitian ke Kesbangpol Badung. Melakukan uji etik untuk mendapatkan ethical clearance. Meneruskan surat izin penelitian ke Desa X, Kecamatan Petang, Badung. Setelah mendapatkan ijin dan pihak Desa $\mathrm{X}$ untuk melakukan penelitian, dilakukan perkenalan kepada subyek penelitian dan menjelaskan maksud dan tujuan serta manfaat penelitian dan diberi surat pernyataan menjadi responden. Selanjutnya peneliti melakukan kontrak waktu untuk melakukan pembagian kuesioner perilaku konsumsi minuman beralkohol dan kuesioner gastritis.Setelah melakukan kontrak waktu dilakukan pembagian informed consent dan kuesioner pada rapat bulanan Sekaa Teruna Teruni (STT) di Desa X, Kecamatan Petang, Badung. Setelah pengisian kuesioner pada responden dilakukan pengumpulan dataSelajutnya dilakukan pengecekan kembali mengenai kelengkapan data yang diperoleh. Data yang diperoleh kemudian dimasukkan kedalam master tabel dan dianalisis dengan uji yang sesuai dengan bantuan komputer.

\section{HASIL PENELITIAN}

Karateristik responden berdasarkan usia menunjukan bahwa sebagian besar responden berada pada rentang usia 2124 tahun yaitu sebanyak 61 orang $(72,6 \%)$. Pada karateristik responden berdasarkan jenis kelamin menunjukan bahwa sebagian besar responden berjenis kelamin laki-laki yaitu sebanyak 77 orang $(91,7 \%)$. Pada karateristik responden berdasarkan tingkat pendidikan menunjukan bahwa sebagian besar responden memiliki tingkat pendidikan SMA/SMK yaitu sebanyak 55 orang $(65,5 \%)$.

Tabel 1 Distribusi Frekuensi Responden berdasarkan Usia, Jenis Kelamin, dan Tingkat Pendidikan Sekaa Teruna Teruni di Desa X, Kecamatan Petang, Kabupaten Badung pada Bulan Mei 2019 (n=84)

\begin{tabular}{lcc}
\hline Usia & $\begin{array}{c}\text { Frekuensi } \\
(\mathbf{n})\end{array}$ & $\begin{array}{c}\text { Persentase } \\
(\boldsymbol{\%})\end{array}$ \\
\hline $17-20$ & 23 & 27,4 \\
\hline $21-24$ & 61 & 72,6 \\
\hline Total & 84 & 100,0 \\
\hline
\end{tabular}




\begin{tabular}{lcc}
\hline Jenis Kelamin & $\begin{array}{c}\text { Frekuensi } \\
(\mathbf{n})\end{array}$ & $\begin{array}{c}\text { Persentase } \\
(\boldsymbol{\%})\end{array}$ \\
\hline Laki-Laki & 77 & 91,7 \\
\hline Perempuan & 7 & 8,3 \\
\hline Total & 84 & 100,0 \\
\hline Tingkat Pendidikan & & \\
& $\begin{array}{c}\text { Frekuensi } \\
(\mathbf{n})\end{array}$ & $\begin{array}{c}\text { Persentase } \\
(\boldsymbol{\%})\end{array}$ \\
\hline SMP & 4 & 4,8 \\
\hline SMA/SMK & 51 & 65,5 \\
\hline Diploma & 9 & 10,7 \\
\hline S1 & 16 & 19,0 \\
\hline Total & 84 & 100,0 \\
\hline
\end{tabular}

Tabel 2 Perilaku Konsumsi Minuman Beralkohol Pada Sekaa Teruna Teruni Di Desa X, Kecamatan Petang, Kabupaten Badung pada Bulan Mei $2019(\mathbf{n = 8 4})$

\begin{tabular}{ccccc} 
Perilaku Konsumsi & SD & Median (Min-Max) & Mean & $95 \% \mathrm{Cl}$ \\
\cline { 2 - 5 } $\begin{array}{c}\text { Minuman } \\
\text { Beralkohol }\end{array}$ & 13.82 & $59.50(20-85)$ & 59.35 & $56.35-62.34$
\end{tabular}

Pada hasil analisis perilaku konsumsi minuman beralkohol dapat dideskripsikan hasil pengukuran perilaku

konsumsi minuman beralkohol pada responden didapatkan nilai median sebesar 59,5

Tabel 3 Gejala Gastritis Pada Sekaa Teruna Teruni Di Desa X, Kecamatan Petang, Kabupaten Badung pada Bulan Mei $2019(\mathbf{n}=84)$

\begin{tabular}{lcccc} 
Gejala Gastritis & SD & Median (Min-Max) & Mean & $95 \% \mathrm{Cl}$ \\
\cline { 2 - 5 } & 5.36 & $22.00(9-37)$ & 22.30 & $21.11-23.44$
\end{tabular}

Hasil analisis gejala gastritis dapat dideskripsikan hasil pengukuran gejala gastritis pada responden didapatkan nilai mean sebesar 22,30.

Tabel 4 Hasil Analisis Korelasi Spearman

\begin{tabular}{cccc}
\hline Variabel & Jumlah $(\mathrm{n})$ & Koef. Korelasi (r) & p value \\
\hline Perilaku Konsumsi & 84 & 0,541 & 0,001 \\
Minuman Beralkohol & & & \\
Gejala Gastritis & & & \\
\hline
\end{tabular}

Untuk menganalisis hubungan perilaku konsumsi minuman beralkohol dengan gejala gastritis digunakan uji Spearman dikarenakan data tidak terdistribusi normal, maka dilakukan uji Spearman dengan tingkat kemaknaan $5 \%$. Berdasarkan hasil analisis bivariat dijelaskan bahwa dari hasil uji diperoleh nilai $p=0,001(<0.05)$ yang menunjukan bahwa kolerasi antara perilaku konsumsi minuman beralkohol dan gejala gastritis bermakna. Nilai korelasi Spearman diperoleh sebesar 0,541 yang menunjukan korelasi positif dengan kekuatan korelasi sedang. 


\section{PEMBAHASAN}

Perilaku alkoholisme merupakan sebuah perilaku penyalahgunaan alkohol yang dilakukan secara rutin atau berulang, perilaku ini diakibatkan karena tidak adanya kontrol dari lingkungan individu. Pada penelitian ini sebagian besar responden berusia 21-24 tahun yang terdiri dari 77 orang laki-laki dan 7 orang perempuan. Berdasarkan hasil dari penelitian diperoleh nilai mean perilaku konsumsi minuman beralkohol pada penelitian ini adalah 59,35 dari skor tertinggi yaitu 100. Gejala gastritis yang paling sering muncul yaitu nyeri pada ulu hati dan mual sesudah makan. Hal ini membuktikan bahwa perilaku konsumsi minuman beralkohol cukup tinggi pada kalangan STT di Desa X. Hal ini sejalan dengan pendapat Djajoesman (2009) yang menyatakan bahwa lingkungan sangat mempengaruhi perilaku mengkonsumsi alkohol seseorang.

Lingkungan merupakan faktor yang sangat mempengaruhi perilaku individu adalah sebuah organisasi yang diikuti (Mahendra, 2016). Berkembangnya perilaku-perilaku baru bisa didapatkan seseorang apabila sudah masuk dalam organisasi salah satunya organisasi STT, baik perilaku positif maupun negatif. Hal tersebut didukung penelitian yang dilakukan oleh Wijaya (2016) didapatkan hasil bahwa faktor yang mempengaruhi seseorang mengkonsumsi minuman beralkohol adalah lingkungan sosial individu tersebut. Perilaku konsumsi minuman beralkohol akan semakin meningkat apabila lingkungan sosial mendukung baik untuk melakukan perilaku konsumsi minuman beralkohol maupun dalam akses mendapatkan minuman beralkohol.

Gastritis merupakan sebuah keadaan dimana terjadinya peradangan pada mukosa lambung yang bersifat akut, kronik, difus dan lokal (Price dan Wilson, 2005). Berdasarkan hasil penelitian yang dilakukan pada 84 responden diperoleh nilai mean 22,30 dari skor total yaitu 45, Hal ini membuktikan bahwa hampir seluruh anggota Sekaa Teruna Teruni di Desa X memiliki gejala gastritis . Hal ini sejalan dengan penelitian Siska (2017) yang menyatakan bahwa pada saat ini remaja rentan mengalami gastritis akibat dari pola hidup yang kurang sehat.

Gejala yang timbul bervariasi mulai dari nyeri pada ulu hati, nafsu makan menurun, perut kembung, mual dan muntah sebelum ataupun sesudah makan, merasa cepat kenyang saat makan dan pada beberapa kasus didapatkan feses berawarna kehitaman (Suratun \& Lusianah, 2010). Hal ini sejalan dengan pendapat Wibowo (2007) yang menyatakan bahwa gejala gastritis terdiri dari gastritis akut dan gastritis kronik. Semua tipe gastritis akut mempunyai gejala yang sama. Gastritis akut dapat menyebabkan gastritis kronik apabila kejadiannya berulangkali dan tidak ditangani. Hal tersebut sejalan dengan penelitian Srianti dan Munawir (2014) dimana gejala yang timbul sesuai dengan faktor pemicu yang menjadi penyebab terjadinya gastritis. Keluhan yang paling sering dijumpai pada kasus ini adalah nyeri pada epigastrium, mual, muntah.

Hasil penelitian yang dilakukan di Desa $X$, Kecamatan Petang, Kabupaten Badung diperoleh nilai $r=0,541$ dengan nilai $p=0,001(p<0,05)$. Hasil tersebut menunjukan bahwa terdapat hubungan antara perilaku konsumsi minuman beralkohol dengan gejala gastritis pada Sekaa Teruna Teruni (STT) dengan arah hubungan positif dengan kekuatan korelasi sedang. Hubungan positif menunjukan bahwa semakin buruk perilaku maka semakin tinggi gejala gastritis pada Sekaa Teruna Teruni (STT). Hasil penelitian ini didukung oleh 
penelitian yang dilakukan oleh Rosalia, Candrawati, Warsono (2017) dimana pada penelitian tersebut didapatkan hasil bahwa mengkonsumsi minuman beralkohol dapat menyebabkan gejala gastritis.

Mengkonsumsi minuman beralkohol dapat merusak dan mengganggu pertahanan mukosa lambung. Alkohol memiliki sifat korosif yaitu dapat merusak sel-sel pada sistem pencernaan. alkohol mengandung etanol yang dapat merusak mukosa lambung, hal ini menimbulkan peradangan sebagai penyebab kejadian gastritis (Djojodiningrat, 2009). Hal ini juga sejalan dengan penelitian Gustin (2014) menyatakan bahwa alkohol dapat merusak mukosa lambung, mengganggu pertahanan mukosa lambung dan memungkinkan difusi kembali asam pepsin ke dalam jaringan lambung, hal ini menimbulkan peradangan. Penelitian dari Srianti dan Munawir (2014) yang menyatakan bahwa mengkonsumsi minuman yang mengandung alkohol berlebih dapat meningkatkan produksi asam lambung, sehingga terjadi iritasi mukosa lambung yang menjadi penyebab seseorang menderita gastritis. Hal ini sejalan dengan penelitian Radu dkk (2018) menyatakan bahwa perilaku konsumsi minuman beralkohol menjadi etiologi penyebab terjadinya gastritis.

Berdasarkan hasil penelitian ini, secara umum dapat disimpulkan bahwa mengkonsumsi minuman beralkohol dapat menyebabkan gastritis dikarenakan alkohol dapat meningkatkan produksi asam lambung sehingga dapat menyebabkan iritasi pada lambung sehingga timbul gastritis.

\section{KESIMPULAN DAN SARAN}

Berdasarkan hasil dan pembahasan penelitian, dapat disimpulkan terdapat hubungan antara perilaku konsumsi minuman beralkohol dengan gejala gastritis pada Sekaa Teruna Teruni dengan arahahubungan positif dengan kekuatan korelasi sedang. Hubungan positif menunjukan bahwa semakin buruk perilaku maka semakin tinggi gejala gastritis. Berdasarkan hasil penelitian, dapat disarankan bagi Sekaa Teruna Teruni diharapkan Sekaa Teruna Teruni mampu untuk mengkontrol perilaku konsumsi minuman beralkohol sehingga dapat mengurangi dampak negatif salah satunya yaitu gastritis.

\section{DAFTAR PUSTAKA}

Saufika, A., Retnaningsih., \& Alfiasari. (2012). Gaya hidup dan kebiasaan makan mahasiswa. Jurnal Ilmu Keluarga dan Konsumen, 157-165

Kant, I., Pandelaki, A. J., \& Lampus B. S. (2013). Gambaran kebiasaan makan masyarakat di perumahan Allandrew Permai Kelurahan Malalayang I Lingkungan XI Kota Manado. JKKT, 88-95.

Utina, S. S. (2011). Alkohol dan pengaruhnya terhadap kesehatan mental. Jurnal IAIN Sultan Amai Gorontalo

Saydam. (2011). Memahami berbagai penyakit (penyakit pernapasan dan gangguan pencernaan). Bandung : Alfabeta

Wibowo, Y. A. (2007). Gastritis. Retrieved from: http://fkuii.org/tikidownloadwiki_att acment.php?attld=1078\&page=yoga \%20agua\%20Wibowo (diakses pada tanggal 20 November 2018)

Rosalia, E. N., Candrawati, E., \& Warsono. (2017). Hubungan konsumsi alkohol dengan nyeri lambung pada mahasiswa laki-laki program studi teknik sipil Universitas Tribhuwana Tunggadewi Malang. Nursing News, 2(3) 
Price, S.A., dan Wilson, L. M., 2005, Patofisiologi: Konsep Klinis Prosesproses Penyakit, Edisi 6, Vol. 2, diterjemahkan oleh Pendit, B. U., Hartanto, H., Wulansari, p., Mahanani, D. A.,Penerbit Buku Kedokteran EGC, Jakarta.

Srianti dan Munawir (2014). Faktor Faktor Yang Berhubungan Dengan Kejadian Gastritis Di Rsud Palagimata Kota Bau - Bau. Jurnal Ilmiah Kesehatan Diagnosis Volume 4 Nomor 6 Tahun 2014 • ISSN : 2302-1721.

I Putu Artha Wijaya (2016). FaktorFaktor Yang Mempengaruhi Tingginya Konsumsi Alkohol Pada Remaja Putra Di Desa Keramas Kecamatan Blahbatuh Kabupaten Gianyar. Jurnal Dunia Kesehatan Vol 5 no 2. 